\title{
Article \\ Electrochemical Toluene Hydrogenation Using Binary Platinum-Based Alloy Nanoparticle-Loaded Carbon Catalysts
}

\author{
Toyoki Imada, Yusuke Iida, Yousuke Ueda, Masanobu Chiku, Eiji Higuchi (D) and Hiroshi Inoue *(D)
}

Department of Applied Chemistry, Graduate School of Engineering, Osaka Prefecture University, Sakai, Osaka 599-8531, Japan; syb01280@edu.osakafu-u.ac.jp (T.I.); sx108077@edu.osakafu-u.ac.jp (Y.I.); su108007@edu.osakafu-u.ac.jp (Y.U.); chiku@chem.osakafu-u.ac.jp (M.C.); e-higuchi@chem.osakafu-u.ac.jp (E.H.)

* Correspondence: inoue-h@chem.osakafu-u.ac.jp; Tel.: +81-72-254-9283

Citation: Imada, T.; Iida, Y.; Ueda, Y.; Chiku, M.; Higuchi, E.; Inoue, $\mathrm{H}$ Electrochemical Toluene

Hydrogenation Using Binary Platinum-Based Alloy NanoparticleLoaded Carbon Catalysts. Catalysts 2021, 11, 318. https://doi.org/ $10.3390 /$ catal11030318

Academic Editor: Vincenzo Baglio

Received: 21 January 2021

Accepted: 24 February 2021

Published: 28 February 2021

Publisher's Note: MDPI stays neutral with regard to jurisdictional claims in published maps and institutional affiliations.

Copyright: (c) 2021 by the authors. Licensee MDPI, Basel, Switzerland. This article is an open access article distributed under the terms and conditions of the Creative Commons Attribution (CC BY) license (https:// creativecommons.org/licenses/by/ $4.0 /)$.
Abstract: A couple of toluene (TL) and its hydrogenation product, methylcyclohexane (MCH), are promising high-density hydrogen carriers to store and transport large amounts of hydrogen. Electrochemical hydrogenation of TL to MCH can achieve energy savings compared with hydrogenation using molecular hydrogen generated separately, and development of highly active catalysts for electrochemical TL hydrogenation is indispensable. In this study, binary $\mathrm{Pt}_{3} \mathrm{M}(\mathrm{M}=\mathrm{Rh}, \mathrm{Au}, \mathrm{Pd}, \mathrm{Ir}$, $\mathrm{Cu}$ and $\mathrm{Ni}$ ) alloy nanoparticle-loaded carbon catalysts were prepared by a colloidal method, and their activity for electrochemical TL hydrogenation was evaluated by linear sweep voltammetry. Each $\mathrm{Pt}_{3} \mathrm{M}$ electrode was initially activated by 100 cycles of potential sweep over a potential range of $0-1.2$ or $0.8 \mathrm{~V}$ vs. reversible hydrogen electrode (RHE). For all activated $\mathrm{Pt}_{3} \mathrm{M}$ electrodes, the cathodic current density for electrochemical TL hydrogenation was observed above $0 \mathrm{~V}$, that is the standard potential of hydrogen evolution reaction. Both specific activity, cathodic current density per electrochemical surface area, and mass activity, cathodic current density per mass of $\mathrm{Pt}_{3} \mathrm{M}$, at $0 \mathrm{~V}$ for the $\mathrm{Pt}_{3} \mathrm{Rh} / \mathrm{C}$ electrode were the highest, and about 8- and 1.2-times as high as those of the commercial $\mathrm{Pt} / \mathrm{C}$ electrode, respectively, which could mainly be attributed to electronic modification of $\mathrm{Pt}$ by alloying with $\mathrm{Rh}$. The Tafel slope for each activated $\mathrm{Pt}_{3} \mathrm{M} / \mathrm{C}$ electrode exhibited the alloying of $\mathrm{Pt}$ with the second metals did not change the electrochemical TL hydrogenation mechanism.

Keywords: hydrogen carrier; organic hydride; toluene/methylcyclohexane; electrochemical hydrogenation; binary Pt-based alloy; $\mathrm{Pt}_{3} \mathrm{Rh}$; electrocatalyst

\section{Introduction}

Most energy comes from fossil fuels, but the use of fossil fuels involves the generation of $\mathrm{CO}_{2}$. Hydrogen is a promising alternative energy source because it has much higher gravimetric energy density $\left(120 \mathrm{MJ} \mathrm{kg}^{-1}\right)$ than gasoline $\left(44 \mathrm{MJ} \mathrm{kg}^{-1}\right)[1,2]$ and its combustion product is only water. Hydrogen gas, however, has the disadvantage of low volumetric energy density $\left(10.8 \mathrm{~kJ} \mathrm{~L}^{-1}\right.$ under atmospheric conditions [2,3]), so there is an urgent need to develop hydrogen carriers that can store and transport large amounts of hydrogen.

Recently, several couples of organic hydrides such as toluene (TL)/methylcyclohexane $(\mathrm{MCH})$ [2-15], benzene/cyclohexane [7-13], naphthalene/decalin [7-11,14-18] and dibenzyltoluene/perhydrodibenzyltoluene $[8,11,14,15]$ whose hydrogen storage capacities were $6.2,7.2,7.3$ and $6.2 \mathrm{wt} \%$, respectively, have been proposed as hydrogen carriers because their hydrogen storage density was much higher than that of commercial hydrogen storage alloys with around 1-2 wt \%. The hydrogen storage capacity of the TL/MCH couple is smaller than the other couples, but both TL and MCH are liquids at ambient temperature and pressure, so that existing infrastructure is available. This is why the TL/MCH couple was chosen as the hydrogen carrier in this study. 
In general, the hydrogenation of TL to $\mathrm{MCH}$ is carried out by adding molecular hydrogen to TL on an appropriate catalyst as follows.

$$
\mathrm{C}_{6} \mathrm{H}_{5} \mathrm{CH}_{3}+3 \mathrm{H}_{2} \rightarrow \mathrm{C}_{6} \mathrm{H}_{11} \mathrm{CH}_{3}
$$

The molecular hydrogen is produced by chemical or electrochemical method. On the other hand, the hydrogenation reaction of $\mathrm{TL}$ to $\mathrm{MCH}$ is also possible using atomic hydrogen electrochemically generated by one-electron reduction of $\mathrm{H}^{+}$in water electrolysis. Hence, direct electrochemical TL hydrogenation to $\mathrm{MCH}$ coupled with water electrolysis is totally represented as follows [19-25].

$$
\begin{aligned}
& \text { Anodic reaction: } 3 \mathrm{H}_{2} \mathrm{O} \rightarrow 3 / 2 \mathrm{O}_{2}+6 \mathrm{H}^{+}+6 \mathrm{e}^{-}(1.23 \mathrm{~V} \text { vs. SHE }) \\
& \text { Cathodic reaction: } \mathrm{C}_{6} \mathrm{H}_{5} \mathrm{CH}_{3}+6 \mathrm{H}^{+}+6 \mathrm{e}^{-} \rightarrow \mathrm{C}_{6} \mathrm{H}_{11} \mathrm{CH}_{3}(0.15 \mathrm{~V} \text { vs. SHE }) \\
& \text { Overall reaction: } \mathrm{C}_{6} \mathrm{H}_{5} \mathrm{CH}_{3}+3 \mathrm{H}_{2} \mathrm{O} \rightarrow \mathrm{C}_{6} \mathrm{H}_{11} \mathrm{CH}_{3}+3 / 2 \mathrm{O}_{2}(1.08 \mathrm{~V} \text { vs. SHE) }
\end{aligned}
$$

The theoretical voltage of the overall reaction is $1.08 \mathrm{~V}$, which is lower than that $(1.23 \mathrm{~V})$ of water electrolysis reaction to generate molecular hydrogen. This clearly indicates that the direct electrochemical hydrogenation (Equation (4)) is more energy saving than the conventional TL hydrogenation with electrochemically generated molecular hydrogen (Equation (1)). In addition, there is no need for a tank to store hydrogen in the former, leading to cost reduction.

The development of highly active catalysts for electrochemical TL hydrogenation is indispensable to suppress hydrogen evolution reaction (HER) as a side reaction. It has been reported that PtRu alloy nanoparticle-loaded carbon black $(\mathrm{PtRu} / \mathrm{C})$ catalysts showed high hydrogenation activity and faradaic efficiency (FE) for $\mathrm{MCH}$ production, which were higher than those of $\mathrm{Pt} / \mathrm{C}[22,23,26,27]$. We also have reported that the $\mathrm{Pt}_{3} \mathrm{Ru}$ alloy nanoparticle-loaded carbon black $\left(\mathrm{Pt}_{3} \mathrm{Ru} / \mathrm{C}\right)$ catalyst exhibited the highest hydrogenation activity among $\mathrm{Pt}_{\mathrm{x}} \mathrm{Ru} / \mathrm{C}(\mathrm{x}=1,3,4)$ catalysts, and $95 \% \mathrm{FE}$ for $\mathrm{MCH}$ production [24]. The $\mathrm{Au} / \mathrm{C}, \mathrm{Pd} / \mathrm{C}, \mathrm{Ru} / \mathrm{C}, \mathrm{Rh} / \mathrm{C}$, and $\mathrm{Ir} / \mathrm{C}$ catalysts were investigated as single precious metal catalysts other than $\mathrm{Pt} / \mathrm{C}$ for electrochemical TL hydrogenation [28]. The $\mathrm{Ru} / \mathrm{C}$ catalyst achieved high FE for $\mathrm{MCH}$ formation even at low metal loading of $1 \mathrm{wt} \%$, but required high overpotential for electrochemical TL hydrogenation. The mixture of $5 \mathrm{wt} \% \mathrm{Ru}$ and $5 \mathrm{wt} \%$ Ir loaded on carbon was comparable to $50 \mathrm{wt} \% \mathrm{Pt}$ supported on carbon in the hydrogenation due to a combination of fast electrochemical reduction of $\mathrm{H}^{+}$on $\mathrm{Ir}$ and fast TL hydrogenation on Ru via spillover of generated atomic hydrogen from Ir to Ru [28-30]. In this way, the synergistic effect of two elements playing different roles is important to enhance the activity for electrochemical TL hydrogenation. Meanwhile, as for binary Pt-based alloy catalysts, to our best knowledge, only $\mathrm{Pt}_{\mathrm{x}} \mathrm{Ru}$ alloys have been available so far. Therefore, to further enhance the hydrogenation activity of the Pt catalyst, searching for a partner to replace ruthenium is essential. In this study, several Pt-based binary alloy, $\mathrm{Pt}_{3} \mathrm{M}(\mathrm{M}=\mathrm{Rh}, \mathrm{Au}, \mathrm{Pd}, \mathrm{Ir}, \mathrm{Cu}$ and $\mathrm{Ni})$ nanoparticle-loaded carbon $\left(\mathrm{Pt}_{3} \mathrm{M} / \mathrm{C}\right)$ catalysts are prepared by the colloidal method [24] and their electrochemical TL hydrogenation activity was evaluated.

\section{Results and Discussion}

2.1. Structural Properties of $\mathrm{Pt}_{3} \mathrm{M} / \mathrm{C}$

Metal loadings of various $\mathrm{Pt}_{3} \mathrm{M} / \mathrm{C}(\mathrm{M}=\mathrm{Rh}, \mathrm{Au}, \mathrm{Pd}, \mathrm{Ir}, \mathrm{Cu}$ and $\mathrm{Ni})$ catalysts are shown in Table 1. For each $\mathrm{Pt}_{3} \mathrm{M} / \mathrm{C}$ catalyst, the evaluated metal loading was close to the theoretical one ( $50 \mathrm{wt} \%$ ), suggesting that the reduction of $\mathrm{Pt}$ and $\mathrm{M}$ precursors was almost completed, and the produced metals were loaded on ketjen black. 
Table 1. Metal loading, $2 \theta$ of (111) peak, lattice parameter and mean crystallite size for $\mathrm{Pt}_{3} \mathrm{M} / \mathrm{C}$ $(\mathrm{M}=\mathrm{Rh}, \mathrm{Au}, \mathrm{Pd}, \mathrm{Ir}, \mathrm{Cu}$ and $\mathrm{Ni})$ catalysts.

\begin{tabular}{ccccc}
\hline Catalyst & $\begin{array}{c}\text { Metal Loading } \\
\mathbf{w t} \%\end{array}$ & $\begin{array}{c}\mathbf{2 \theta} \text { of (111) Peak } \\
\text { Degree }\end{array}$ & $\begin{array}{c}\text { Lattice Parameter } \\
\mathbf{n m}\end{array}$ & $\begin{array}{c}\text { Mean Crystallite Size } \\
\mathbf{n m}\end{array}$ \\
\hline $\mathrm{Pt}_{3} \mathrm{Rh} / \mathrm{C}$ & 46.1 & 40.20 & 0.388 & 3.2 \\
$\mathrm{Pt}_{3} \mathrm{Au} / \mathrm{C}$ & 46.5 & $38.42,39.80$ & $0.405,0.392$ & 3.7 \\
$\mathrm{Pt}_{3} \mathrm{Pd} / \mathrm{C}$ & 50.0 & 40.16 & 0.389 & 4.8 \\
$\mathrm{Pt}_{3} \mathrm{Ir} / \mathrm{C}$ & 45.7 & 40.00 & 0.390 & 4.4 \\
$\mathrm{Pt}_{3} \mathrm{Cu} / \mathrm{C}$ & 47.9 & 40.52 & 0.385 & 3.4 \\
$\mathrm{Pt}_{3} \mathrm{Ni} / \mathrm{C}$ & 44.0 & 40.08 & 0.389 & 3.0 \\
$\mathrm{Pt}(1)$ & - & 39.76 & 0.392 & - \\
\hline
\end{tabular}

(1) ICDD 00-004-0802.

Figure 1 shows X-ray diffraction $(\mathrm{XRD})$ patterns of the $\mathrm{Pt}_{3} \mathrm{M} / \mathrm{C}$ catalysts. All catalysts had a single diffraction peak around $40^{\circ}$ and $47^{\circ}$, which were close to the (111) and (200) peaks of platinum (ICDD 00-004-0802) with face-centered cubic (fcc) crystal structure, respectively, suggesting that $\mathrm{Pt}$ and $\mathrm{M}$ in metallic phase for each catalyst were alloyed. For the catalysts other than $\mathrm{Pt}_{3} \mathrm{Au} / \mathrm{C}$, the (111) peak shifted towards higher angles compared to that of pure $\mathrm{Pt}$, indicating that the lattice parameter of each catalyst is smaller than that of pure $\mathrm{Pt}$, as shown in Table 1, because the radii of the second metals are smaller than that of Pt. In contrast, the $\mathrm{Pt}_{3} \mathrm{Au} / \mathrm{C}$ had additional two peaks around $38.42^{\circ}$ and $44.74^{\circ}$, which has also been reported previously [31]. This suggests that phase segregation occurred in this catalyst. These diffraction peaks shifted towards higher angles than the (111) and (200) peaks $\left(38.18^{\circ}\right.$ and $\left.44.39^{\circ}\right)$ for gold (ICDD 00-004-0784), suggesting the formation of a binary Au-rich alloy. As shown in Table 1, the $2 \theta$ value of the main (111) peak for $\mathrm{Pt}_{3} \mathrm{Au} / \mathrm{C}$ was almost the same as that for pure $\mathrm{Pt}$, suggesting the existence of the $\mathrm{Pt}$ nanoparticles.

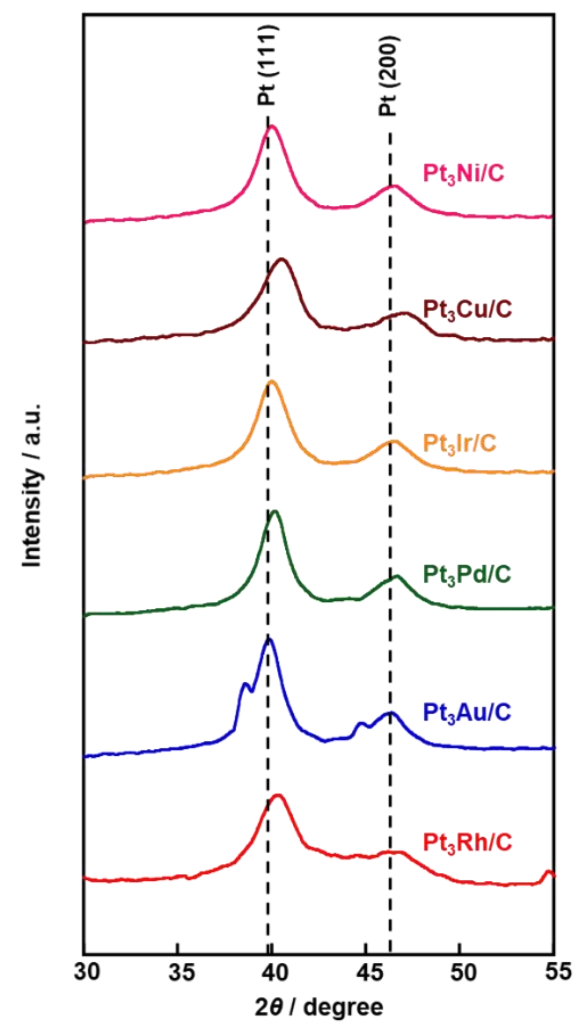

Figure 1. $\mathrm{XRD}$ patterns of $\mathrm{Pt}_{3} \mathrm{M} / \mathrm{C}(\mathrm{M}=\mathrm{Rh}, \mathrm{Au}, \mathrm{Pd}, \mathrm{Ir}, \mathrm{Cu}$ and $\mathrm{Ni})$ catalysts. 
The mean crystallite size of each $\mathrm{Pt}_{3} \mathrm{M}$ nanoparticle loaded on ketjen black was estimated with Scherrer's equation (Equation (5)) for the (111) peak in each XRD pattern assuming a single $\mathrm{Pt}_{\mathrm{x}} \mathrm{M}$ phase, and summarized in Table 1.

$$
L=0.9 \lambda /(B \cos \theta)
$$

where $L$ is the mean crystallite size $(\mathrm{nm}), \lambda$ is the wavelength of the $\mathrm{X}$-ray $(0.1541 \mathrm{~nm})$, $\theta$ is the Bragg angle of the (111) peak, and $B$ is the width (radian) of the (111) peak at half height [32,33]. The mean crystallite size was $3.0-4.8 \mathrm{~nm}$, which was relatively close to each other.

Figures S1 and S2 (Supplementary Materials) show transmission electron microscope (TEM) images and size distribution profiles of nanoparticles for $\mathrm{Pt}_{3} \mathrm{M} / \mathrm{C}$ catalysts. The mean crystallite size of each catalyst estimated from its XRD pattern (Table 1) was in good agreement with that estimated from the corresponding TEM image.

Figure 2 shows $\mathrm{Pt} 4 \mathrm{f}$ and $\mathrm{Rh} 3 \mathrm{~d}, \mathrm{Au} 4 \mathrm{f}, \mathrm{Pd} 3 \mathrm{~d}, \mathrm{Ir} 4 \mathrm{f}, \mathrm{Cu} 2 \mathrm{p}$ or Ni $2 \mathrm{p}$ core level spectra for the $\mathrm{Pt}_{3} \mathrm{M} / \mathrm{C}\left(\mathrm{M}=\mathrm{Rh}, \mathrm{Au}, \mathrm{Pd}, \mathrm{Ir}, \mathrm{Cu}\right.$ and Ni) catalysts. For the $\mathrm{Pt}_{3} \mathrm{Rh} / \mathrm{C}$ catalyst, $\mathrm{Rh} 3 \mathrm{~d}$ spectrum exhibited doublets at 307.4 and $312.3 \mathrm{eV}$ due to metallic $\mathrm{Rh}\left(\mathrm{Rh}^{0}\right)$, which were higher in binding energy than pure $\mathrm{Rh}^{0}(307.0$ and $311.7 \mathrm{eV})$ [34]. For the $\mathrm{Pt}_{3} \mathrm{Au} / \mathrm{C}$ catalyst, $\mathrm{Au} 4 \mathrm{f}$ spectrum exhibited doublets at 84.0 and $87.7 \mathrm{eV}$ due to metallic $\mathrm{Au}\left(\mathrm{Au}^{0}\right)$, which almost agree with those of pure $\mathrm{Au}^{0}\left(84.0\right.$ and $87.7 \mathrm{eV}$ ) [35]. For the $\mathrm{Pt}_{3} \mathrm{Pd} / \mathrm{C}$ catalyst, Pd $3 d$ spectrum exhibited doublets at 335.5 and $340.9 \mathrm{eV}$ due to metallic $\mathrm{Pd}\left(\mathrm{Pd}^{0}\right)$, which were higher in binding energy than pure $\mathrm{Pd}^{0}$ (335.2 and $340.5 \mathrm{eV}$ ) [36]. For the $\mathrm{Pt}_{3} \mathrm{Ir} / \mathrm{C}$ catalyst, Ir $4 \mathrm{f}$ spectrum exhibited doublets at 61.2 and $64.4 \mathrm{eV}$ due to metallic $\operatorname{Ir}\left(\operatorname{Ir}^{0}\right)$, which were higher in binding energy than pure $\operatorname{Ir}^{0}(60.9$ and $63.8 \mathrm{eV})$ [37]. Additionally, the $\mathrm{Ir}$ $4 \mathrm{f}$ spectrum exhibited doublets at 66.1 and $62.9 \mathrm{eV}$ [38] because iridium was oxidized to cations with valences of 4 or more in the air. For the $\mathrm{Pt}_{3} \mathrm{Cu} / \mathrm{C}$ catalyst, $\mathrm{Cu} 2 \mathrm{p}$ spectrum exhibited doublets at 932.2 and $952.1 \mathrm{eV}$ due to metallic $\mathrm{Cu}\left(\mathrm{Cu}^{0}\right)$, which were lower in binding energy than pure $\mathrm{Cu}^{0}\left(932.5\right.$ and $952.3 \mathrm{eV}$ ) [39]. Additionally, the $\mathrm{Cu} 2 \mathrm{p}_{3 / 2}$ peak at $934.6 \mathrm{eV}$ and $\mathrm{Cu} 2 \mathrm{p}_{1 / 2}$ peak at $954.6 \mathrm{eV}$ due to $\mathrm{CuO}$ were observed with the satellite peaks at $941.5,944.3$ and $963.8 \mathrm{eV}[39,40]$. For the $\mathrm{Pt}_{3} \mathrm{Ni} / \mathrm{C}$ catalyst, $\mathrm{Ni} 2 \mathrm{p}$ spectrum exhibited singlet at $852.7 \mathrm{eV}$ due to metallic $\mathrm{Ni}\left(\mathrm{Ni}^{0}\right)$, which was higher in binding energy than pure $\mathrm{Ni}^{0}(852.4 \mathrm{eV})$ [41]. Also the Ni $2 \mathrm{p}$ spectrum exhibited doublets at 857.2 and $874.8 \mathrm{eV}$ due to $\mathrm{Ni}(\mathrm{OH})_{2}$ with the satellite peaks at 861.2 and $880.2 \mathrm{eV}[42,43]$. In all $\mathrm{Pt}_{3} \mathrm{M} / \mathrm{C}$ catalysts, $\mathrm{Pt} 4 \mathrm{f}$ spectrum exhibited doublets due to metallic $\mathrm{Pt}\left(\mathrm{Pt}^{0}\right)$, which were higher in binding energy than pure $\mathrm{Pt}^{0}$ (71.1 and $74.4 \mathrm{eV}$ ) [44]. These results also support the alloying of $\mathrm{Pt}$ with the second metals.

The bulk composition and surface composition of the $\mathrm{Pt}_{3} \mathrm{M} / \mathrm{C}$ catalysts were evaluated by energy dispersive X-ray (EDX) and X-ray photoelectron spectroscopy (XPS), respectively, and summarized in Table 2. The bulk composition of $\mathrm{Pt}_{3} \mathrm{Ir} / \mathrm{C}$, however, could not be evaluated because the Pt and Ir peaks in the EDX spectrum overlapped each other. The bulk composition for $\mathrm{Pt}_{3} \mathrm{M} / \mathrm{C}$ catalysts other than $\mathrm{Pt}_{3} \mathrm{Au} / \mathrm{C}$ was close to the theoretical one ( $\mathrm{Pt} 75$ at \% and $\mathrm{M} 25$ at \%), and the $\mathrm{Pt} / \mathrm{M}$ atomic ratio calculated from the bulk composition was 2.8-3.5. Thus, the composition of each catalyst is nominally represented as $\mathrm{Pt}_{3} \mathrm{M}$ hereafter. For the $\mathrm{Pt}_{3} \mathrm{Au} / \mathrm{C}$ alloy, the surface composition was significantly different from the bulk composition probably because of the phase segregation and/or partial dissolution of the surface $\mathrm{Au}$ atoms into the $\mathrm{Pt}$ and $\mathrm{Au}$-rich alloy particles. 


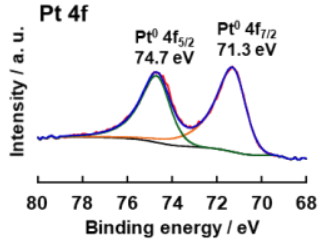

(a) $\mathrm{Pt}_{3} \mathrm{Rh} / \mathrm{C}$

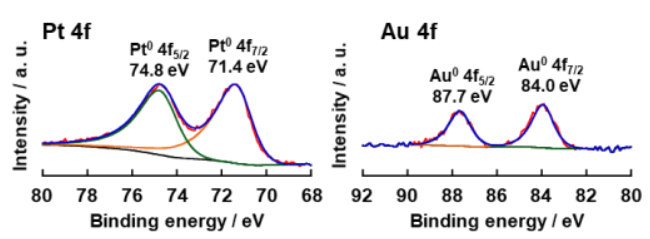

(b) $\mathrm{Pt}_{3} \mathrm{Au} / \mathrm{C}$

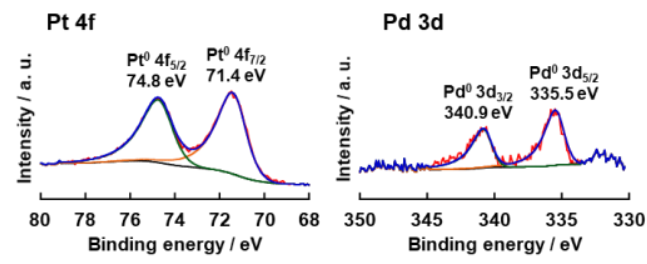

(c) $\mathrm{Pt}_{3} \mathrm{Pd} / \mathrm{C}$

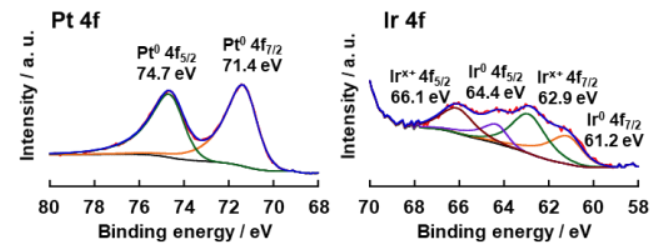

(d) $\mathrm{Pt}_{3} \mathrm{Ir} / \mathrm{C}$
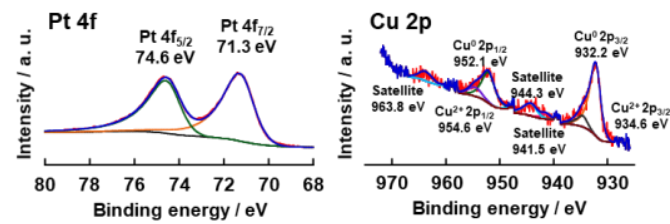

(e) $\mathrm{Pt}_{3} \mathrm{Cu} / \mathrm{C}$

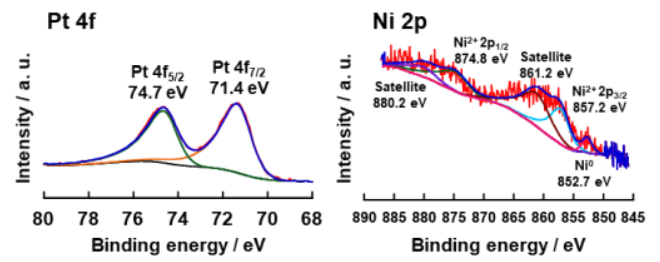

(f) $\mathrm{Pt}_{3} \mathrm{Ni} / \mathrm{C}$

Figure 2. Pt4f and Rh3d, Au4f, Pd3d, Ir4f, Cu2p or Ni2p core level spectra for (a) $\mathrm{Pt}_{3} \mathrm{Rh} / \mathrm{C},(\mathbf{b}) \mathrm{Pt}_{3} \mathrm{Au} / \mathrm{C},(\mathbf{c}) \mathrm{Pt}_{3} \mathrm{Pd} / \mathrm{C},(\mathrm{d})$ $\mathrm{Pt}_{3} \mathrm{Ir} / \mathrm{C},(\mathbf{e}) \mathrm{Pt}_{3} \mathrm{Cu} / \mathrm{C}$ and (f) $\mathrm{Pt}_{3} \mathrm{Ni} / \mathrm{C}$ catalysts.

Table 2. Surface composition, bulk composition, metal loading mass and mean crystallite size for $\mathrm{Pt}_{3} \mathrm{M} / \mathrm{C}(\mathrm{M}=\mathrm{Rh}, \mathrm{Au}, \mathrm{Pd}$, $\mathrm{Ir}, \mathrm{Cu}$ and $\mathrm{Ni}$ ) catalysts as prepared and after the linear sweep voltammetry measurement for electrochemical toluene (TL) hydrogenation.

\begin{tabular}{|c|c|c|c|c|c|c|c|}
\hline \multirow{2}{*}{ Catalyst } & & \multicolumn{2}{|c|}{ Surface Composition ${ }^{(1)}$} & \multicolumn{2}{|c|}{ Bulk Composition (2) } & \multirow{2}{*}{$\begin{array}{c}\text { Metal Loading } \\
\text { Mass }\end{array}$} & \multirow{2}{*}{$\begin{array}{c}\begin{array}{c}\text { Mean } \\
\text { Crystallite Size }\end{array} \\
\mathrm{nm}\end{array}$} \\
\hline & & Pt/at \% & M/at \% & Pt/at \% & M/at \% & & \\
\hline \multirow{2}{*}{$\mathrm{Pt}_{3} \mathrm{Rh} / \mathrm{C}$} & As prepared & 77.5 & 22.5 & 74.4 & 25.6 & 3.40 & 3.2 \\
\hline & After LSV ${ }^{(3)}$ & 89.7 & 10.3 & 79.2 & 20.8 & 3.28 & 4.4 \\
\hline \multirow{2}{*}{$\mathrm{Pt}_{3} \mathrm{Au} / \mathrm{C}$} & As prepared & 87.2 & 12.8 & 73.0 & 27.0 & 3.05 & 3.7 \\
\hline & After LSV (3) & 87.5 & 12.5 & 72.5 & 27.5 & 3.05 & 5.3 \\
\hline \multirow{2}{*}{$\mathrm{Pt}_{3} \mathrm{Pd} / \mathrm{C}$} & As prepared & 73.3 & 26.7 & 73.7 & 26.3 & 2.85 & 4.8 \\
\hline & After LSV ${ }^{(3)}$ & 90.6 & 9.40 & 84.3 & 15.7 & 2.63 & 5.4 \\
\hline \multirow{2}{*}{$\mathrm{Pt}_{3} \mathrm{Ir} / \mathrm{C}$} & As prepared & 72.2 & 27.8 & - & - & 3.35 & 4.4 \\
\hline & After LSV ${ }^{(3)}$ & 85.9 & 14.1 & - & - & 2.82 & 4.8 \\
\hline \multirow{2}{*}{$\mathrm{Pt}_{3} \mathrm{Cu} / \mathrm{C}$} & As prepared & 79.4 & 20.6 & 77.7 & 22.3 & 2.90 & 3.4 \\
\hline & After LSV ${ }^{(4)}$ & 96.3 & 3.7 & 89.6 & 10.4 & 2.75 & 4.0 \\
\hline \multirow{2}{*}{$\mathrm{Pt}_{3} \mathrm{Ni} / \mathrm{C}$} & As prepared & 75.3 & 24.7 & 76.8 & 23.2 & 3.05 & 3.0 \\
\hline & After LSV ${ }^{(4)}$ & 100 & 0 & 94.3 & 5.7 & 2.85 & 3.7 \\
\hline
\end{tabular}

(1) By XPS; ${ }^{(2)}$ by EDX; ${ }^{(3)}$ initial activation: $0.05-1.2 \mathrm{~V}$ vs. reversible hydrogen electrode (RHE); ${ }^{(4)}$ initial activation: $0.05-0.8 \mathrm{~V}$ vs. RHE.

\subsection{Electrochemical TL Hydrogenation Activity with $\mathrm{Pt}_{3} \mathrm{M} / \mathrm{C}$ Electrodes}

Figure 3 shows cyclic voltammograms (CVs) of the $\mathrm{Pt}_{3} \mathrm{M} / \mathrm{C}$ electrodes after initial activation to clean the electrode surface before evaluating the electrochemical TL hydrogenation activity. The initial activation was performed by 100 cycles of potential sweep over the potential range of 0.05-1.2 V vs. RHE for the $\mathrm{Pt}_{3} \mathrm{Rh} / \mathrm{C}, \mathrm{Pt}_{3} \mathrm{Au} / \mathrm{C}, \mathrm{Pt}_{3} \mathrm{Pd} / \mathrm{C}$ and $\mathrm{Pt}_{3} \mathrm{Ir} / \mathrm{C}$ electrodes, and $0.05-0.8 \mathrm{~V}$ vs. $\mathrm{RHE}$ for the $\mathrm{Pt}_{3} \mathrm{Cu} / \mathrm{C}$ and $\mathrm{Pt}_{3} \mathrm{Ni} / \mathrm{C}$ electrodes because $\mathrm{Cu}$ and $\mathrm{Ni}$ were easier to be oxidatively dissolve than the noble metals. In general, a polycrystalline Pt electrode has two couples of redox peaks due to hydrogen adsorption/desorption 
between 0.05 and $0.4 \mathrm{~V}$ vs. RHE [44,45]. Each $\mathrm{Pt}_{3} \mathrm{M}$ electrode also had these redox peaks, as shown in Figure 4, although they were not distinctly separated. The electric charge for the desorption of atomic hydrogen $\left(Q_{\mathrm{H}-\mathrm{des}}\right)$ for a polycrystalline $\mathrm{Pt}$ is $210 \mu \mathrm{C} \mathrm{cm}{ }^{-2}$ [45], indicating that an atomic hydrogen is adsorbed on a Pt atom. The oxidation peaks due to hydrogen desorption for pure $\mathrm{Rh}, \mathrm{Pd}$ and $\mathrm{Ir}$ electrodes partly overlap those for the polycrystalline Pt electrode [46,47], but not for pure $\mathrm{Au}, \mathrm{Cu}$ and $\mathrm{Ni}$ electrodes. If binary Pt-based alloys maintain the fcc structure and the atomic radii of $\mathrm{Pt}$ and foreign metals are similar to each other, the $Q_{\mathrm{H} \text {-des }}$ value of $210 \mu \mathrm{C} \mathrm{cm}^{-2}$ is often used, supposing that each constituent (M) has a stoichiometric composition of $\mathrm{M}: \mathrm{H}=1: 1$ [48]. The $\mathrm{Pt}_{3} \mathrm{Rh}_{1} \mathrm{Pt}_{3} \mathrm{Pd}$ and $\mathrm{Pt}_{3} \mathrm{Ir}$ alloys have the fcc structure, as can be seen from Figure 1 . So, the electrochemical surface areas (ECSAs) of these electrodes were calculated with the $Q_{\mathrm{H}-\text { des }}$ values estimated from their CVs in Figure 3 as follows, supposing $210 \mu \mathrm{C} \mathrm{cm}$.

$$
\mathrm{ECSA}=Q_{\mathrm{H}-\mathrm{des}} / 210
$$

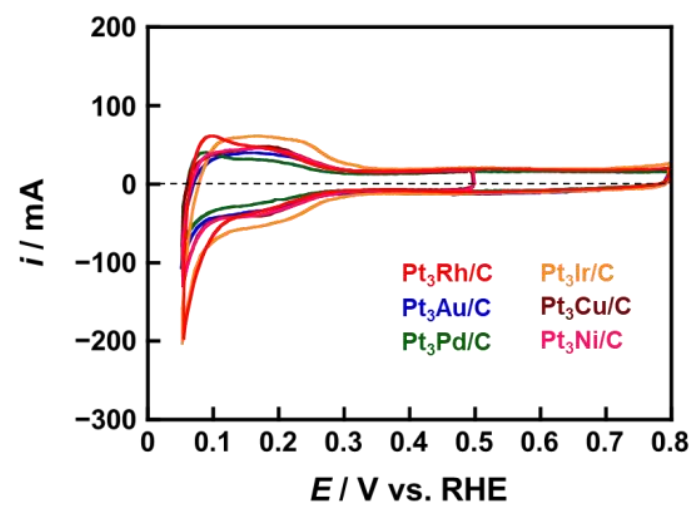

Figure 3. Cyclic voltammograms (CVs) of the $\mathrm{Pt}_{3} \mathrm{M} / \mathrm{C}(\mathrm{M}=\mathrm{Rh}, \mathrm{Au}, \mathrm{Pd}, \mathrm{Ir}, \mathrm{Cu}$ and $\mathrm{Ni})$ electrodes after the initial activation. Sweep rate: $50 \mathrm{mV} \mathrm{s}^{-1}$.
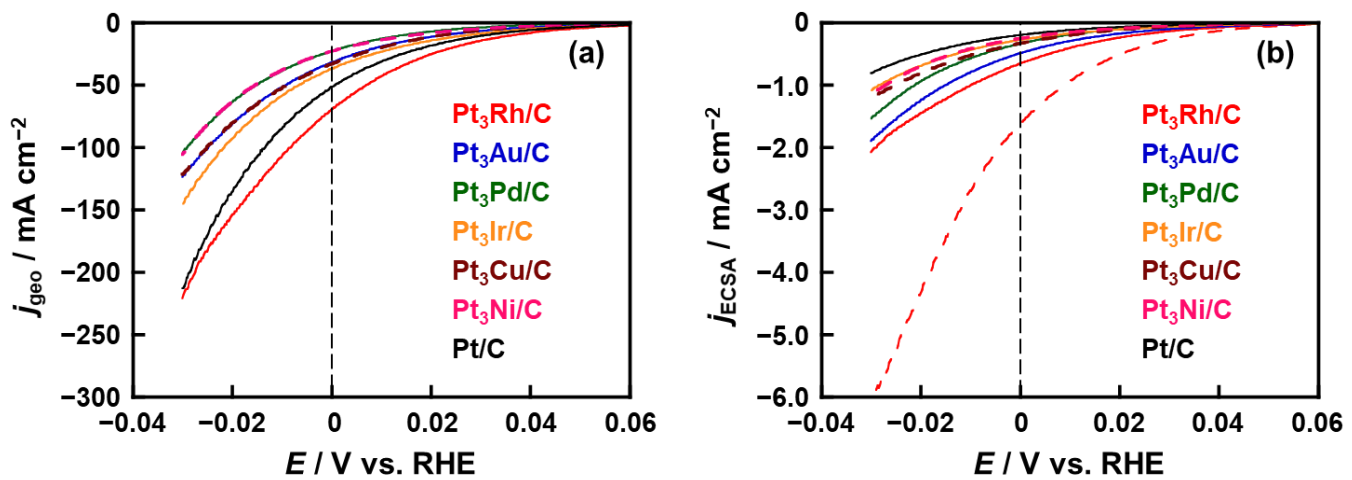

Figure 4. Linear sweep voltammograms (LSVs) of activated $\mathrm{Pt}_{3} \mathrm{M} / \mathrm{C}(\mathrm{M}=\mathrm{Rh}, \mathrm{Au}, \mathrm{Pd}, \mathrm{Ir}, \mathrm{Cu}$ and Ni) electrodes represented by (a) $j_{\text {geo }}$ and (b) $j_{\mathrm{ECSA}}$. Sweep rate: $1 \mathrm{mV} \mathrm{s}^{-1}$. Solid and broken curves show the initial activation potential range of $0.05-1.2 \mathrm{~V}$ and $0.05-0.8 \mathrm{~V}$ vs. RHE, respectively.

The ECSAs of the $\mathrm{Pt}_{3} \mathrm{Rh} / \mathrm{C}, \mathrm{Pt}_{3} \mathrm{Pd} / \mathrm{C}$ and $\mathrm{Pt}_{3} \mathrm{Ir} / \mathrm{C}$ electrodes, which are the sum of ECSA for the Pt and M surfaces, were evaluated to be 532,339 and $673 \mathrm{~cm}^{2}$, respectively. On the other hand, for the $\mathrm{Pt}_{3} \mathrm{Au} / \mathrm{C}, \mathrm{Pt}_{3} \mathrm{Cu} / \mathrm{C}$ and $\mathrm{Pt}_{3} \mathrm{Ni} / \mathrm{C}$ electrodes, the ECSA estimated from the $Q_{\mathrm{H}-\mathrm{des}}$ value will be quite equal to that of the Pt constituent surface of each alloy. The ECSAs of the $\mathrm{Pt}_{3} \mathrm{Au} / \mathrm{C}, \mathrm{Pt}_{3} \mathrm{Cu} / \mathrm{C}$ and $\mathrm{Pt}_{3} \mathrm{Ni} / \mathrm{C}$ electrodes were 325,500 and $455 \mathrm{~cm}^{2}$, respectively.

Figure 4 shows the linear sweep voltammograms (LSVs) of activated $\mathrm{Pt}_{3} \mathrm{M} / \mathrm{C}(\mathrm{M}=\mathrm{Rh}$, $\mathrm{Au}, \mathrm{Pd}, \mathrm{Ir}, \mathrm{Cu}$ and $\mathrm{Ni}$ ) and commercial $\mathrm{Pt} / \mathrm{C}$ electrodes at a sweep rate of $50 \mathrm{mV} \mathrm{s}^{-1}$ when 
neat TL was supplied into the cathode compartment of the electrochemical hydrogenation cell. The initial activation was performed by 100 cycles of potential sweep over the potential range of $0.05-1.2 \mathrm{~V}$ vs. RHE for the $\mathrm{Pt}_{3} \mathrm{Rh} / \mathrm{C}, \mathrm{Pt}_{3} \mathrm{Au} / \mathrm{C}, \mathrm{Pt}_{3} \mathrm{Pd} / \mathrm{C}, \mathrm{Pt}{ }_{3} \mathrm{Ir} / \mathrm{C}$ and $\mathrm{Pt} / \mathrm{C}$ electrodes, and $0.05-0.8 \mathrm{~V}$ vs. RHE for the $\mathrm{Pt}_{3} \mathrm{Cu} / \mathrm{C}$ and $\mathrm{Pt}_{3} \mathrm{Ni} / \mathrm{C}$ electrodes. Figure $4 \mathrm{a}, \mathrm{b}$ are represented by the geometric current density $\left(j_{\text {geo }}\right)$, and current density per ECSA $\left(j_{\mathrm{ECSA}}\right)$ or specific activity $(\mathrm{SA})$, respectively. In Figure $4 \mathrm{a}$, the onset potential of $j_{\text {geo }}\left(E_{\text {onset }}\right)$

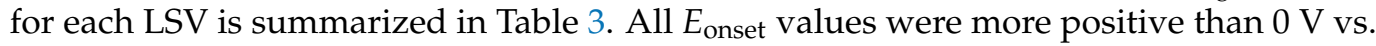
RHE or the standard potential for HER, suggesting that the cathodic current density of each LSV is attributed to the electrochemical TL hydrogenation [49].

Table 3. $m_{\mathrm{a}}, E_{\text {onset }}, j_{\text {geo, } 0}$ and Tafel slope for the activated $\mathrm{Pt}_{3} \mathrm{M} / \mathrm{C}(\mathrm{M}=\mathrm{Rh}, \mathrm{Au}, \mathrm{Pd}, \mathrm{Ir}, \mathrm{Cu}$ and Ni) electrodes.

\begin{tabular}{|c|c|c|c|c|}
\hline Electrode & $\begin{array}{l}m_{\mathrm{a}} \\
\mathrm{mg}\end{array}$ & $\begin{array}{c}E_{\text {onset }} \\
\text { V vs. RHE }\end{array}$ & $\begin{array}{c}j_{\text {geo,0 }} \\
\mathrm{mA} \mathrm{cm}^{-2}\end{array}$ & $\begin{array}{l}\text { Tafel Slope } \\
\text { mV dec }^{-1}\end{array}$ \\
\hline $\mathrm{Pt}_{3} \mathrm{Rh} / \mathrm{C}$ & 4.3 & 0.074 & 70 & 38 \\
\hline $\mathrm{Pt}_{3} \mathrm{Au} / \mathrm{C}$ & 5.3 & 0.060 & 32 & 41 \\
\hline $\mathrm{Pt}_{3} \mathrm{Pd} / \mathrm{C}$ & 5.4 & 0.046 & 23 & 37 \\
\hline $\mathrm{Pt}_{3} \mathrm{Ir} / \mathrm{C}$ & 4.8 & 0.067 & 37 & 42 \\
\hline $\mathrm{Pt}_{3} \mathrm{Cu} / \mathrm{C}$ & 4.0 & 0.053 & 33 & 31 \\
\hline $\mathrm{Pt}_{3} \mathrm{Ni} / \mathrm{C}$ & 3.7 & 0.068 & 23 & 35 \\
\hline
\end{tabular}

The $j_{\text {geo }}$ and $j_{\mathrm{ECSA}}$ values at $0 \mathrm{~V}$ vs. $\operatorname{RHE}\left(j_{\text {geo, }, 0}\right.$ and $\left.\mathrm{SA}_{0}\right)$ were evaluated from each LSV in Figure 4 to use as measures of electrochemical TL hydrogenation activity. The results are summarized in Table 3 and Figure 5. The $\mathrm{SA}_{0}$ was the highest for the $\mathrm{Pt}_{3} \mathrm{Rh} / \mathrm{C}$ electrode, and decreased in the order of $\mathrm{Pt}_{3} \mathrm{Rh} / \mathrm{C}>\mathrm{Pt}_{3} \mathrm{Au} / \mathrm{C}>\mathrm{Pt}_{3} \mathrm{Pd} / \mathrm{C}>\mathrm{Pt}_{3} \mathrm{Cu} / \mathrm{C}>$ $\mathrm{Pt}_{3} \mathrm{Ir} / \mathrm{C}>\mathrm{Pt}_{3} \mathrm{Ni} / \mathrm{C}>\mathrm{Pt} / \mathrm{C}$. This indicates that the alloying of $\mathrm{Pt}$ with the second metals is effective for improving electrochemical TL hydrogenation activity of $\mathrm{Pt}$.
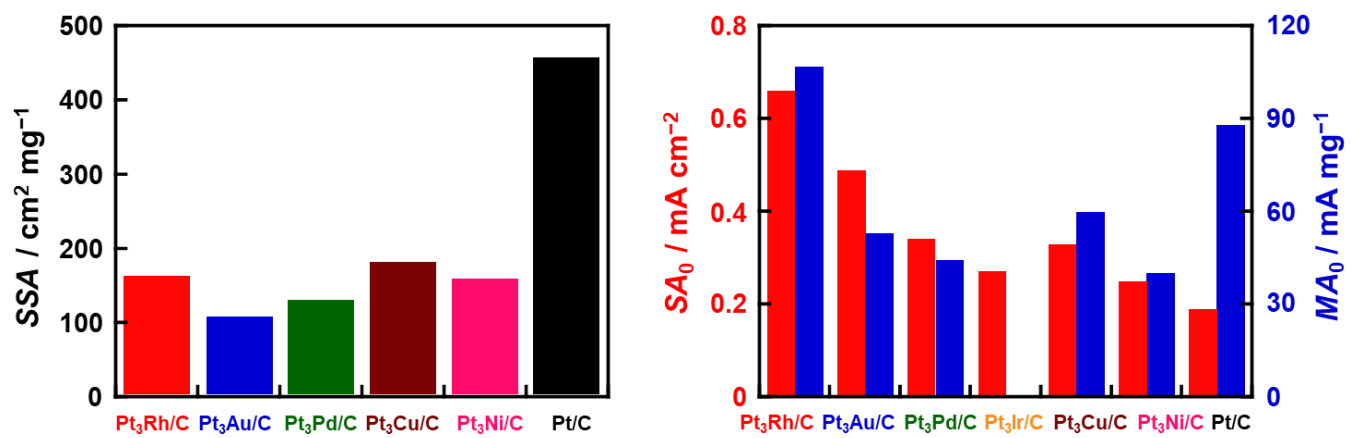

Figure 5. Specific surface area (SSA), $\mathrm{SA}_{0}$ and $\mathrm{MA}_{0}$ of activated $\mathrm{Pt}_{3} \mathrm{M} / \mathrm{C}(\mathrm{M}=\mathrm{Rh}, \mathrm{Au}, \mathrm{Pd}, \mathrm{Cu}$ and Ni) electrodes.

Remarkably, for the $\mathrm{Pt}_{3} \mathrm{Rh} / \mathrm{C}$ electrode, when the initial activation potential range was changed to $0.05-0.8 \mathrm{~V}$ vs. RHE, the $j_{\mathrm{ECSA}}$ or SA greatly increased, as shown in Figure $4 \mathrm{~b}$. The $\mathrm{SA}_{0}$ value was $1.60 \mathrm{~mA} \mathrm{~cm}{ }^{-2}$, which is about 2.4, 8.4 and 1.8-times as high as that for the $\mathrm{Pt}_{3} \mathrm{Rh} / \mathrm{C}$ electrode with the initial activation between 0.05 and $1.2 \mathrm{~V}$ vs. RHE, the $\mathrm{Pt} / \mathrm{C}$ electrode and the $\mathrm{Pt}_{3} \mathrm{Ru} / \mathrm{C}$ electrode [24] probably due to the increased surface $\mathrm{Rh}$ content, respectively. It has been reported that electrochemical TL hydrogenation activity for pure Rh was lower than that for pure $\mathrm{Pt}[27,28]$. Moreover, we have reported that the electrochemical TL hydrogenation activity for Rh-modified $\mathrm{Pt} / \mathrm{C}$ catalysts, in which $\mathrm{Rh}$ did not form any alloys with $\mathrm{Pt}$, was the maximum 2.7-times that for the commercial $\mathrm{Pt} / \mathrm{C}$ catalyst due to the increase in the extent of the interface between $\mathrm{Pt}$ and $\mathrm{Rh}$ resulting from the modification of the Pt surface with Rh [49]. In contrast, the present $\mathrm{Pt}_{3} \mathrm{Rh}$ alloy was homogeneous, as expected from the XRD pattern (Figure 1), and the Rh content is about one-third of the Pt content, so the domains consisting of only Rh atoms will not have been formed in the alloy. Therefore, in the present study, the Rh constituent seems to contribute 
to the electronic modification of $\mathrm{Pt}$ atoms. In our previous study with $\mathrm{Rh}$-modified $\mathrm{Pt} / \mathrm{C}$ catalysts, the first step of electrochemical TL hydrogenation or one-electron reduction of $\mathrm{H}^{+}$to atomic hydrogen was anticipated to proceed on the Rh sites [49]. So, the surface $\mathrm{Rh}$ sites of the $\mathrm{Pt}_{3} \mathrm{Rh}$ alloy may also contribute to facilitating the first step.

To investigate the stability of the $\mathrm{Pt}_{3} \mathrm{M} / \mathrm{C}$ catalysts during the initial activation and the following LSV measurement for electrochemical TL hydrogenation, bulk composition and surface composition of each catalyst after the LSV measurement were evaluated by EDX and XPS (Figure S3, Supplementary Materials), respectively, and summarized in Table 2. For the $\mathrm{Pt}_{3} \mathrm{M} / \mathrm{C}$ electrodes other than $\mathrm{Pt}_{3} \mathrm{Au}$, both surface and bulk contents of the second metals decreased after the LSV measurement, and the decrease in the surface content was larger than that in the bulk content because the second metals were easier to oxidatively dissolve than Pt. Presumably, the oxidative dissolution of the second metals proceeded during the initial activation, not during the LSV measurement. For the $\mathrm{Pt}_{3} \mathrm{Au} / \mathrm{C}$ catalyst, the Au constituent was not oxidized under the initial activation conditions, so the surface composition hardly changed during the initial activation.

The mean crystallite size of each $\mathrm{Pt}_{3} \mathrm{M}$ alloy after the LSV measurement for electrochemical TL hydrogenation was estimated from the XRD pattern (Figure S4, Supplementary Materials), and summarized in Table 2. In all cases, the mean crystallite size increased after the LSV measurement. There are several styles of particle growth: (1) Ostwald ripening, (2) coalescence of metal nanoparticles via migration on the carbon support, and (3) metal nanoparticle agglomeration triggered by the corrosion of carbon support [50]. In the present study, the surface and bulk contents of the second metals in the $\mathrm{Pt}_{3} \mathrm{M}$ alloys were reduced by the oxidative dissolution of the second metals during the initial activation, so the particle growth seemed to be mainly due to the coalescence of metal nanoparticles via migration on the carbon support.

Mass activity (MA), cathodic current density per mass of $\mathrm{Pt}_{3} \mathrm{M}$ alloy, is also another measure of electrochemical TL hydrogenation activity. The higher MA leads to the smaller catalyst amount, so the higher MA is desirable from a practical point of view. To calculate MA, it is not suitable to use the initial loading mass of metals because the second metals other than Au can oxidatively dissolve during the initial activation. The metal loading mass after the LSV measurement $\left(m_{\mathrm{a}}\right)$ can be calculated using the metal loading mass and bulk composition of the as-prepared $\mathrm{Pt}_{3} \mathrm{M} / \mathrm{C}$ catalyst and the bulk composition after the LSV measurement (Table 2), assuming that only the second metal constituent in each $\mathrm{Pt}_{3} \mathrm{M}$ alloy dissolves [24]. The $m_{\mathrm{a}}$ value of each $\mathrm{Pt}_{3} \mathrm{M} / \mathrm{C}$ electrode is summarized in Table 3. In addition, the $\mathrm{MA}_{0}$ and specific surface area (SSA) for each $\mathrm{Pt}_{3} \mathrm{M} / \mathrm{C}$ catalyst were calculated using the ma value, and shown in Figure 5 . As can be seen from Figure 5, the $\mathrm{MA}_{0}$ value $\left(107 \mathrm{~mA} \mathrm{mg}^{-1}\right)$ of the $\mathrm{Pt}_{3} \mathrm{Rh} / \mathrm{C}$ electrode was the highest in the $\mathrm{Pt}_{3} \mathrm{M} / \mathrm{C}$ electrodes, and higher than that $\left(88 \mathrm{~mA} \mathrm{mg}{ }^{-1}\right)$ of the commercial $\mathrm{Pt} / \mathrm{C}$ electrode. The $\mathrm{MA}_{0}$ value is a product of $\mathrm{SA}_{0}$ and SSA. For SSA, the Pt/C electrode $\left(456 \mathrm{~cm}^{2} \mathrm{mg}^{-1}\right)$ was much larger than the $\mathrm{Pt}_{3} \mathrm{Rh} / \mathrm{C}$ electrode $\left(162 \mathrm{~cm}^{2} \mathrm{mg}^{-1}\right)$, because the mean size (ca. $2.6 \mathrm{~nm}$ [49]) of $\mathrm{Pt}$ nanoparticles is smaller than that $(4.4 \mathrm{~nm})$ of $\mathrm{Pt}_{3} \mathrm{Rh}$ nanoparticles. For $\mathrm{SA}_{0}$, the $\mathrm{Pt}_{3} \mathrm{Rh} / \mathrm{C}$ electrode was much larger than the $\mathrm{Pt} / \mathrm{C}$ electrode. Overall, the increase in $\mathrm{SA}_{0}$ outweighs the decrease in SSA, leading to the increase in $\mathrm{MA}_{0}$. Therefore, the electronic modification of $\mathrm{Pt}$ by alloying with $\mathrm{Rh}$ has a great influence on the high $\mathrm{MA}_{0}$ for $\mathrm{Pt}_{3} \mathrm{Rh} / \mathrm{C}$ electrode.

To discuss the reaction mechanism for the electrochemical TL hydrogenation on each $\mathrm{Pt}_{3} \mathrm{M} / \mathrm{C}$ electrode, the Tafel slope was evaluated. Figure 6 shows the Tafel plots made from the LSVs in Figure 4, and the Tafel slopes are summarized in Table 3. Electrochemical TL hydrogenation is known to consist of the following elemental reactions $[19,20]$.

$$
\begin{gathered}
\mathrm{H}^{+}+\mathrm{e}^{-} \rightarrow \mathrm{H}_{\mathrm{ads}} \\
\mathrm{C}_{6} \mathrm{H}_{5} \mathrm{CH}_{3}+6 \mathrm{H}_{\mathrm{ads}} \rightarrow \mathrm{C}_{6} \mathrm{H}_{11} \mathrm{CH}_{3}
\end{gathered}
$$




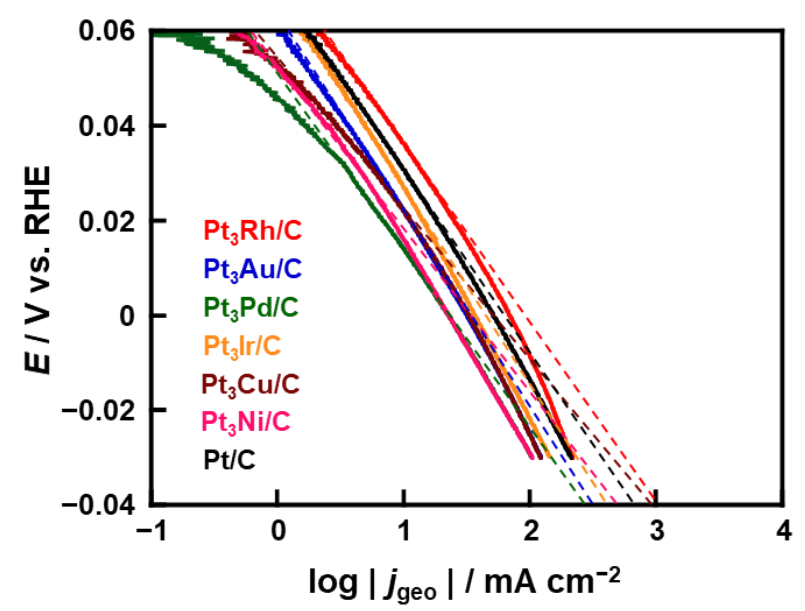

Figure 6. Tafel plots of activated $\mathrm{Pt}_{3} \mathrm{M} / \mathrm{C}(\mathrm{M}=\mathrm{Rh}, \mathrm{Au}, \mathrm{Pd}, \mathrm{Ir}, \mathrm{Cu}$ and $\mathrm{Ni}$ ) electrodes.

The first step or one-electron reduction reaction of $\mathrm{H}^{+}$to atomic hydrogen $\left(\mathrm{H}_{\mathrm{ads}}\right)$ is the same reaction as the Volmer reaction in HER, and the second step is the MCH formation reaction by adding the adsorbed $\mathrm{H}_{\mathrm{ads}}$ to TL. In the HER on a Pt electrode, if the Volmer reaction is the rate-determining step, the Tafel slope is $120 \mathrm{mV} \mathrm{dec}^{-1}$, whereas if the Tafel

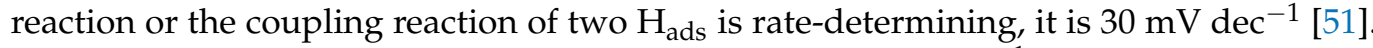
In Table 3, the Tafel slope of the Pt/C electrode was $39 \mathrm{mV} \mathrm{dec}^{-1}$, which was similar to that reported previously [49]. This strongly suggests that the rate-determining step of electrochemical TL hydrogenation on $\mathrm{Pt} / \mathrm{C}$ is the second step (Equation (7)). Moreover, as can be seen from Table 3, the Tafel slope of each $\mathrm{Pt}_{3} \mathrm{M} / \mathrm{C}$ electrode was similar to that of the $\mathrm{Pt} / \mathrm{C}$ electrode, indicating that each $\mathrm{Pt}_{3} \mathrm{M} / \mathrm{C}$ electrode has the same rate-determining step as the $\mathrm{Pt} / \mathrm{C}$ electrode or the alloying of $\mathrm{Pt}$ with various second metals do not change the electrochemical TL hydrogenation mechanism.

\section{Materials and Methods}

\subsection{Chemicals and Materials}

Tetraoctylammonium bromide $\left(\mathrm{N}(\mathrm{Oct})_{4} \mathrm{Br}, 97.0 \%\right)$, tetrahydrofuran (THF, super dehydrated, stabilizer free, 99.5\%), platinum chloride $\left(\mathrm{PtCl}_{2}, 98.0 \%\right)$, rhodium chloride trihydrate $\left(\mathrm{RhCl}_{3} \bullet 3 \mathrm{H}_{2} \mathrm{O}, 99.5 \%\right)$, iridium chloride $\left(\mathrm{IrCl}_{3}, 97.0 \%\right)$, palladium chloride $\left(\mathrm{PdCl}_{2}\right.$, 99.0\%), gold chloride $\left(\mathrm{AuCl}_{3}, 95.0 \%\right)$, silver chloride $(\mathrm{AgCl}, 99.5 \%)$, 2-propanol (guaranteed reagent, $99.7 \%$ ), acetone (guaranteed reagent, 99.5\%), toluene (super dehydrated, 99.5\%), methylcyclohexane (special grade, 98.0\%) were purchased from Fujifilm Wako Pure Chemical Co (Osaka, Japan). Nafion ${ }^{\circledR}$ perfluorinated resin aqueous dispersion (15-20 wt \% in $\mathrm{H}_{2} \mathrm{O}, \mathrm{EW}=1100$ ) and $1.0 \mathrm{M}$ potassium triethylborohydride solution in tetrahydrofuran $(\mathrm{THF})\left(1.0 \mathrm{M} \mathrm{K}\left[\mathrm{BEt}_{3} \mathrm{H}\right] / \mathrm{THF}\right)$ were purchased from Sigma-Aldrich (St. Louis, MO, USA). Ketjen black (EC300J, $800 \mathrm{~m}^{2} \mathrm{~g}^{-1}$ ) was purchased from Lion Specialty Chemicals Co (Tokyo, Japan). Nafion ${ }^{\circledR} 212$ membrane was purchased from Du Pont Co (Wilmington, DE,

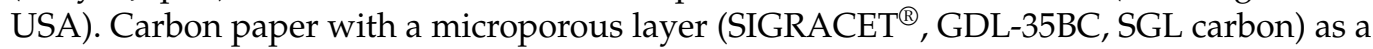
gas diffusion layer, $\mathrm{Pt}$ nanoparticle-loaded carbon catalyst as anode (Pt/C, Tanaka Kikinzoku Kogyo, TEC10E50E, Pt loading: $46.1 \mathrm{wt} \%$ ) and an electrochemical cell (FC05-01SP, ElectroChem, Inc., Woburn, MA, USA) were used for electrochemical TL hydrogenation.

\subsection{Preparation of $P t_{3} M / C(M=R h, A u, P d, I r, C u, N i)$ Catalysts}

$\mathrm{Pt}_{3} \mathrm{M} / \mathrm{C}(\mathrm{M}=\mathrm{Rh}, \mathrm{Au}, \mathrm{Pd}, \mathrm{Ir}, \mathrm{Cu}, \mathrm{Ni})$ catalysts were prepared by a colloidal method using ketjen black as a support and $\mathrm{N}(\mathrm{Oct})_{4} \mathrm{BEt}_{3} \mathrm{H}\left(\mathrm{Oct}:-\mathrm{C}_{8} \mathrm{H}_{17}, \mathrm{Et}:-\mathrm{C}_{2} \mathrm{H}_{5}\right)$ as a reducing agent and stabilizer. At first, $\mathrm{N}(\mathrm{Oct})_{4} \mathrm{BEt}_{3} \mathrm{H}$ was prepared according to Ref. 52 . $\mathrm{N}(\mathrm{Oct})_{4} \mathrm{Br}$ $(5.0 \mathrm{mg}, 9.2 \mathrm{mmol})$ in THF $(11 \mathrm{~mL})$ was mixed with $1.0 \mathrm{M} \mathrm{K}\left[\mathrm{BEt}_{3} \mathrm{H}\right] / \mathrm{THF}(9.2 \mathrm{~mL})$ in an $\mathrm{Ar}$ atmosphere, followed by stirring for $1 \mathrm{~h}$. The resultant white suspension was preserved at $0{ }^{\circ} \mathrm{C}$ in an $\mathrm{Ar}$ atmosphere. After that, $\mathrm{N}(\mathrm{Oct})_{4} \mathrm{BEt}_{3} \mathrm{H}$ was isolated by suction filtration, 
thoroughly washed with THF and dried. The next, each $\mathrm{Pt}_{3} \mathrm{M} / \mathrm{C}$ catalyst was prepared according to Ref. 53. $\mathrm{PtCl}_{2}(133 \mathrm{mg})$ and $\mathrm{MCl}_{\mathrm{x}}(\mathrm{M}=\mathrm{Rh}, \mathrm{Au}, \mathrm{Pd}, \mathrm{Ir}, \mathrm{Cu}$ or Ni) were put into the two-necked round-bottom flask, and then THF $(200 \mathrm{~mL})$ was poured to dissolve the metal precursors. The $\mathrm{Pt} / \mathrm{M}$ mole ratio was fixed to 3 . A solution $(16 \mathrm{~mL})$ of $0.3 \mathrm{M}$ $\mathrm{N}(\mathrm{Oct})_{4} \mathrm{BEt}_{3} \mathrm{H}$ in THF was dropwise into the precursor solution at $40{ }^{\circ} \mathrm{C}$ with stirring in an $\mathrm{Ar}$ atmosphere for $3 \mathrm{~h}$ to make a black suspension. To oxidize excess $\mathrm{N}(\mathrm{Oct})_{4}\left(\mathrm{BEt}_{3} \mathrm{H}\right)$, acetone $(15 \mathrm{~mL})$ was added into the resultant black suspension, followed by stirring it for 30 min. ketjen black was added to the $\mathrm{Pt}_{3} \mathrm{M}$ colloidal solution to become the theoretical metal loading of $50 \mathrm{wt} \%$, followed by sonicating it for $1 \mathrm{~h}$. After suction filtration in air, a residual black powder was collected, thoroughly washed with ultrapure water, and dried in vacuum at room temperature. Finally, it was heat-treated at $200{ }^{\circ} \mathrm{C}$ in air for $30 \mathrm{~min}$ to remove $\mathrm{N}(\mathrm{Oct})_{4} \mathrm{Cl}$.

\subsection{Characterizations of $P t_{3} M / C$ Catalysts}

To determine the metal loading of each catalyst, thermogravimetry (TG) was performed with the Thermo Plus TG8120 apparatus (Rigaku, Akishima, Japan) by heating the sample from room temperature to $800^{\circ} \mathrm{C}$ in air at a rate of $1 \mathrm{~K} \mathrm{~min}^{-1}$. Each sample was heated from room temperature to $800{ }^{\circ} \mathrm{C}$ in air at a rate of $1 \mathrm{~K} \mathrm{~min}^{-1}$. The contents of $\mathrm{Pt}$ and $\mathrm{M}$ in at.\% for each catalyst were evaluated by EDX analysis (VE-9800, Keyence, Osaka, Japan). The crystal structure of each catalyst was characterized by XRD measurements using the XRD-6100 diffraction instrument (Shimadzu, Kyoto, Japan) with $\mathrm{Cu} \mathrm{K} \alpha$ radiation $(\lambda=0.15405 \mathrm{~nm}, 50 \mathrm{kV}, 30 \mathrm{~mA})$. The particle size of each catalyst was characterized by TEM (JEM-2000FX, JEOL Ltd., Akishima, Japan). The size distribution profiles of the $\mathrm{Pt}_{3} \mathrm{M}$ nanoparticles for $\mathrm{Pt}_{3} \mathrm{M} / \mathrm{C}$ were obtained by directly measuring the sizes of 300 random nanoparticles chosen from several TEM images. The electronic state of each catalyst was analyzed by performing XPS using the ESCA-3400 instrument (Shimazu, Kyoto, Japan) with $\mathrm{Mg} \mathrm{K} \alpha$ radiation $(1253.6 \mathrm{eV}, 10 \mathrm{kV}, 20 \mathrm{~mA})$. Binding energies of XPS spectra were calibrated by using Au $4 \mathrm{f}_{7 / 2}$ peak of gold powder as $84.0 \mathrm{eV}$.

\subsection{Preparation of $\mathrm{Pt}_{3} \mathrm{M} / \mathrm{C}$ Electrodes and Membrane-Electrode Assemblies}

Each catalyst ink was prepared by mixing the $\mathrm{Pt}_{3} \mathrm{M} / \mathrm{C}$ powder, ultrapure water, 2-propanol and $5 \mathrm{wt} \%$ Nafion ${ }^{\circledR}$ perfluorinated resin aqueous dispersion in a zirconia container $(45 \mathrm{~mL})$, and then ball-milling at $30 \mathrm{~m} \mathrm{~s}^{-2}$ for $2 \mathrm{~h}$ using a planetary ball-mill (P-7, Fritsch Japan Co., Ltd., Yokohama, Japan). The Nafion ${ }^{\circledR} /$ Carbon support mass ratio in the catalyst ink was fixed to 0.8 . The resultant catalyst ink was spread over the microporous layer side of the commercial carbon paper using a bar-coater (Matsuo Sangyo, K-coater), followed by drying it at $80^{\circ} \mathrm{C}$ for $30 \mathrm{~min}$ to prepare a gas-diffusion electrode (GDE). The resultant $\mathrm{Pt}_{3} \mathrm{M} / \mathrm{C}$-loaded GDE is named $\mathrm{Pt}_{3} \mathrm{M} / \mathrm{C}$ electrode hereafter.

To prepare a membrane-electrode assembly (MEA), a Nafion ${ }^{\circledR}$ membrane (NRE212, $50 \mu \mathrm{m}$, Du Pont Co, Wilmington, DE, USA) was sandwiched between a $\mathrm{Pt}_{3} \mathrm{M} / \mathrm{C}$ electrode as the cathode and a Pt/C electrode as the anode, and hot-pressed at $130^{\circ} \mathrm{C}$ and $1.0 \mathrm{MPa}$ for $3 \mathrm{~min}$. The geometric surface areas of the cathode and anode were $5 \mathrm{~cm}^{2}$.

\subsection{Electrochemical Hydrogen Pump TL Hydrogenation with $\mathrm{Pt}_{3} \mathrm{M} / \mathrm{C}$ Electrodes}

A commercial electrochemical cell (FC05-01SP, ElectroChem, Inc., Woburn, MA, USA) was used for electrochemical measurements. All electrochemical measurements were carried out at $50{ }^{\circ} \mathrm{C} . \mathrm{N}_{2}$ and $\mathrm{H}_{2}$ gases of $0.1 \mathrm{MPa}$ were fed into the cathode and anode

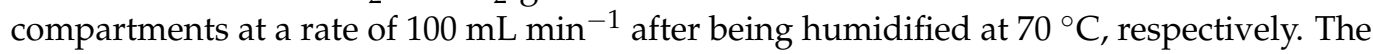
anode was also used as the reference electrode (RHE). Each cathode was initially activated by 100 cycles of potential sweeps at $50 \mathrm{mV} \mathrm{s}^{-1}$ between 0.05 and $0.8 \mathrm{~V}$ vs. RHE or between 0.05 and $1.2 \mathrm{~V}$ vs. RHE with flowing the humidified $\mathrm{N}_{2}$ gas. A CV was measured at $50 \mathrm{mV} \mathrm{s}^{-1}$ between 0.05 and $0.8 \mathrm{~V}$ vs. RHE to evaluate ECSA.

An electrochemical hydrogen pump TL hydrogenation system used in this study is

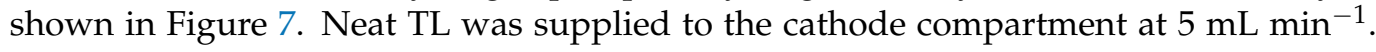


LSVs were measured at $1 \mathrm{mV} \mathrm{s}^{-1}$ from an open circuit potential to $-0.03 \mathrm{~V}$ vs. RHE to evaluate the activity of each catalyst for electrochemical TL hydrogenation. All potentials were corrected by IR drop.

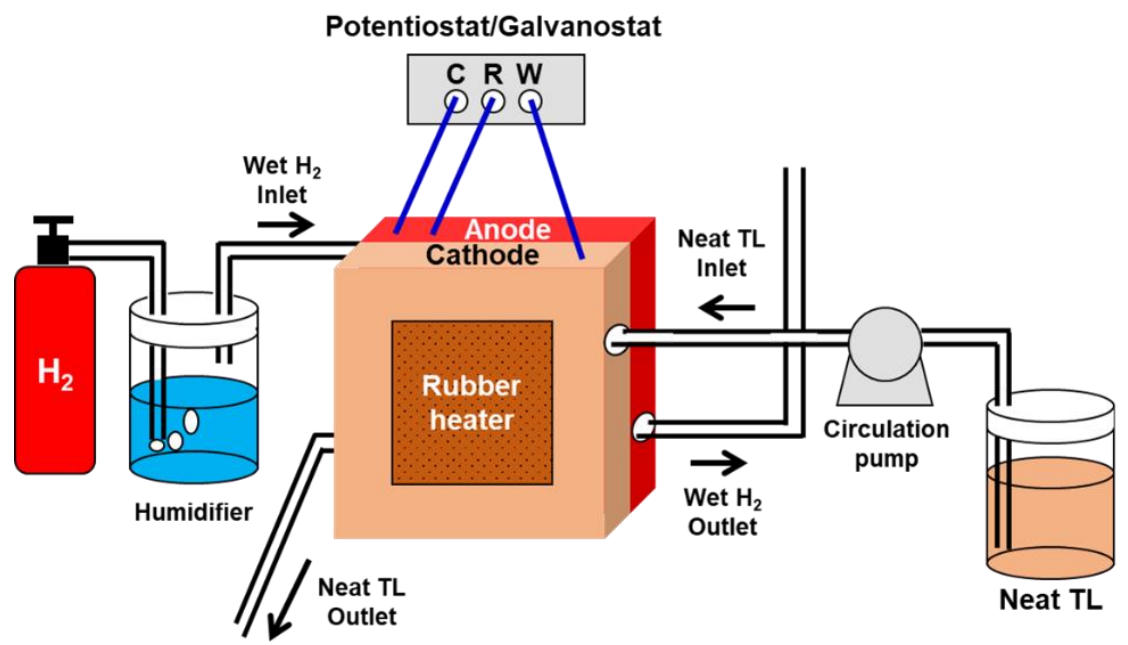

Figure 7. A schematic diagram of electrochemical hydrogen pump TL hydrogenation system.

\section{Conclusions}

In this study, the binary $\mathrm{Pt}_{3} \mathrm{M}(\mathrm{M}=\mathrm{Rh}, \mathrm{Au}, \mathrm{Pd}, \mathrm{Ir}, \mathrm{Cu}$ and $\mathrm{Ni})$ alloy nanoparticleloaded carbon catalysts were prepared by colloidal method. The metal loadings and bulk compositions for the as-prepared $\mathrm{Pt}_{3} \mathrm{M} / \mathrm{C}$ catalysts were close to the theoretical ones, suggesting the complete reduction of the $\mathrm{Pt}$ and $\mathrm{M}$ precursors. The XRD patterns of $\mathrm{Pt}_{3} \mathrm{M} / \mathrm{C}$ catalysts other than $\mathrm{Pt}_{3} \mathrm{Au} / \mathrm{C}$ were similar to of polycrystalline $\mathrm{Pt}$ with the fcc structure, and the lattice parameter in the former was smaller than that in the latter, suggesting that $\mathrm{Pt}$ and $\mathrm{M}$ in metallic phase for each catalyst were alloyed. The $\mathrm{Pt}_{3} \mathrm{Au} / \mathrm{C}$ catalyst was segregated to $\mathrm{Pt}$ and binary Au-rich alloy phases. The mean crystallite size for the $\mathrm{Pt}_{3} \mathrm{M} / \mathrm{C}$ catalysts was $3.0-4.8 \mathrm{~nm}$, which was relatively close to each other. The crystallite size of each catalyst estimated from its XRD pattern was in good agreement with that estimated from the corresponding TEM image. In core-level spectrum of each constituent for the $\mathrm{Pt}_{3} \mathrm{M} / \mathrm{C}$ catalysts, a peak shift was observed, suggesting the formation of the binary alloy.

When neat TL was supplied to the cathode compartment of the electrochemical hydrogenation cell, the $E_{\text {onset }}$ was more positive than $0 \mathrm{~V}$ vs. RHE or the standard potential of HER, suggesting that cathodic current density of each LSV was attributed to electrochemical TL hydrogenation. The $\mathrm{SA}_{0}$ value was the highest for the $\mathrm{Pt}_{3} \mathrm{Rh} / \mathrm{C}$ electrode, and decreased in the order of $\mathrm{Pt}_{3} \mathrm{Rh} / \mathrm{C}>\mathrm{Pt}_{3} \mathrm{Au} / \mathrm{C}>\mathrm{Pt}_{3} \mathrm{Pd} / \mathrm{C}>\mathrm{Pt}_{3} \mathrm{Cu} / \mathrm{C}>\mathrm{Pt}_{3} \mathrm{Ir} / \mathrm{C}>$ $\mathrm{Pt}_{3} \mathrm{Ni} / \mathrm{C}>\mathrm{Pt} / \mathrm{C}$. This indicates that the alloying of $\mathrm{Pt}$ with the second metals is effective for improving electrochemical TL hydrogenation activity of Pt. Remarkably, for the $\mathrm{Pt}_{3} \mathrm{Rh} / \mathrm{C}$ electrode, when the initial activation potential range was changed to $0.05-0.8 \mathrm{~V}$ vs. RHE, the $\mathrm{SA}_{0}$ value was about 2.4, 8.4 and 1.8-times as high as that for the $\mathrm{Pt}_{3} \mathrm{Rh} / \mathrm{C}$ electrode with the initial activation between 0.05 and $1.2 \mathrm{~V}$ vs. RHE, the Pt/C electrode and the previous $\mathrm{Pt}_{3} \mathrm{Ru} / \mathrm{C}$ electrode, respectively due to electronic modification of $\mathrm{Pt}$ atoms with the Rh constituent.

After the LSV measurement, both surface and bulk contents of the second metal for the $\mathrm{Pt}_{3} \mathrm{M} / \mathrm{C}$ catalysts other than $\mathrm{Pt}_{3} \mathrm{Au}$ decreased, and the decrease in surface content was larger than that in bulk content due to the oxidative dissolution of each constituent during the initial activation, whereas the mean crystallite size increased mainly due to the coalescence of metal nanoparticles via migration on the carbon support.

The $\mathrm{MA}_{0}$ value of the $\mathrm{Pt}_{3} \mathrm{Rh} / \mathrm{C}$ electrode was the highest in the $\mathrm{Pt}_{3} \mathrm{M} / \mathrm{C}$ electrodes, and higher than that of the commercial $\mathrm{Pt} / \mathrm{C}$ electrode. This is mainly attributed to the increase in $\mathrm{SA}_{0}$ or the electronic modification of Pt by alloying with Rh. The Tafel slope of each activated $\mathrm{Pt}_{3} \mathrm{M} / \mathrm{C}$ electrode was similar to that of the $\mathrm{Pt} / \mathrm{C}$ electrode, indicating that 
each activated $\mathrm{Pt}_{3} \mathrm{M} / \mathrm{C}$ electrode has the same rate-determining step as the $\mathrm{Pt} / \mathrm{C}$ electrode or the alloying of $\mathrm{Pt}$ with various second metals do not change the electrochemical TL hydrogenation mechanism.

Supplementary Materials: The following are available online at https://www.mdpi.com/2073 -4344/11/3/318/s1, Figure S1: TEM images of nanoparticles for (a) $\mathrm{Pt}_{3} \mathrm{Rh} / \mathrm{C},(\mathbf{b}) \mathrm{Pt}_{3} \mathrm{Au} / \mathrm{C}$, (c) $\mathrm{Pt}_{3} \mathrm{Pd} / \mathrm{C}$, (d) $\mathrm{Pt}_{3} \mathrm{Ir} / \mathrm{C},(\mathbf{e}) \mathrm{Pt}_{3} \mathrm{Cu} / \mathrm{C}$ and $(\mathbf{f}) \mathrm{Pt}_{3} \mathrm{Ni} / \mathrm{C}$ catalysts. Figure S2. Size distribution profiles of nanoparticles for (a) $\mathrm{Pt}_{3} \mathrm{Rh} / \mathrm{C}$, (b) $\mathrm{Pt}_{3} \mathrm{Au} / \mathrm{C}$, (c) $\mathrm{Pt}_{3} \mathrm{Pd} / \mathrm{C}$, (d) $\mathrm{Pt}_{3} \mathrm{Ir} / \mathrm{C}$, (e) $\mathrm{Pt}_{3} \mathrm{Cu} / \mathrm{C}$ and (f) $\mathrm{Pt}_{3} \mathrm{Ni} / \mathrm{C}$ catalysts. Figure S3: Pt4f and Rh3d, Au4f, Pd3d, Ir4f, Cu2p or Ni2p core level spectra for (a) $\mathrm{Pt}_{3} \mathrm{Rh} / \mathrm{C}$, (b) $\mathrm{Pt}_{3} \mathrm{Au} / \mathrm{C}$, (c) $\mathrm{Pt}_{3} \mathrm{Pd} / \mathrm{C}$, (d) $\mathrm{Pt}_{3} \mathrm{Ir} / \mathrm{C}$, (e) $\mathrm{Pt}_{3} \mathrm{Cu} / \mathrm{C}$ and (f) $\mathrm{Pt}_{3} \mathrm{Ni} / \mathrm{C}$ catalysts after the LSV measurement, Figure S4: XRD patterns of $\mathrm{Pt}_{3} \mathrm{M} / \mathrm{C}(\mathrm{M}=\mathrm{Rh}, \mathrm{Au}, \mathrm{Pd}, \mathrm{Ir}, \mathrm{Cu}$ and $\mathrm{Ni}$ ) catalysts after the LSV measurement.

Author Contributions: Conceptualization, H.I.; preparation of catalysts, measurements of XRD, EDX and XPS measurements and electrochemical experiments, T.I., Y.I., and Y.U.; analysis of the mean crystallite size, particle size, metal loading of each alloy and specific and mass activities for electrochemical TL hydrogenation, T.I., M.C., and E.H.; writing-original draft preparation, T.I.; writing-review and editing, H.I.; supervision, H.I.; writing and editing, H.I. and T.I.; funding acquisition, H.I. All authors have read and agreed to the published version of the manuscript.

Funding: This work was funded by the Council for Science, Technology and Innovation (CSTI), Cross-ministerial Strategic Innovation Promotion Program (SIP), and "Energy Carrier" (funding agency: JST).

Conflicts of Interest: The authors declare no conflict of interest.

\section{References}

1. Satyapal, S.; Petrovic, J.; Read, C.; Thomas, G.; Ordaz, G. The U.S. department of energy's national hydrogen storage project: Progress towards meeting hydrogen-powered vehicle requirements. Catal. Today 2007, 120, 246-256. [CrossRef]

2. Wijayanta, A.T.; Oda, T.; Chandra, W.; Purnomo, C.W.; Kashiwagi, T.; Aziz, M. Liquid hydrogen, methylcyclohexane, and ammonia as potential hydrogen storage: Comparison review. Int. J. Hydrogen Energy 2019, 44, 15026-15044. [CrossRef]

3. Aziz, M.; Juangsa, F.B.; Kurniawan, W.; Budiman, B.A. Clean Co-production of $\mathrm{H}_{2}$ and power from low rank coal. Energy 2016, 116, 489-497. [CrossRef]

4. Shukla, A.A.; Gosavi, P.V.; Pande, J.V.; Kumar, V.P.; Chary, K.V.R.; Biniwale, R.B. Efficient hydrogen supply through catalytic dehydrogenation of methylcyclohexane over Pt/metal oxide catalysts. Int. J. Hydrogen Energy 2010, 35, 4020-4026. [CrossRef]

5. Tsunemi, K.; Yoshida, K.; Yoshida, M.; Kato, E.; Kawamoto, A.; Kihara, T.; Saburi, T. Estimation of consequence and damage caused by an organic hydride hydrogen refueling station. Int. J. Hydrogen Energy 2017, 42, 26175-26182. [CrossRef]

6. Furukawa, S.; Matsunami, Y.; Hamada, I.; Hashimoto, Y.; Sato, Y.; Komatsu, T. Remarkable enhancement in hydrogenation ability by phosphidation of ruthenium: Specific surface structure having unique Ru ensembles. ACS Catal. 2018, 8, 8177-8181. [CrossRef]

7. Okada, Y.; Sasaki, E.; Watanabe, E.; Hyodo, S.; Nishijima, H. Development of dehydrogenation catalyst for hydrogen generation in organic chemical hydride method. Int. J. Hydrogen Energy 2006, 31, 1348-1356. [CrossRef]

8. Modisha, P.M.; Ouma, C.N.M.; Garidzirai, R.; Wasserscheid, P.; Bessarabov, D. The prospect of hydrogen storage using liquid organic hydrogen carriers. Energy Fuels 2019, 33, 2778-2796. [CrossRef]

9. Kariya, N.; Fukuoka, A.; Utagawa, T.; Sakuramoto, M.; Goto, Y.; Ichikawa, M. Efficient hydrogen production using cyclohexane and decalin by pulse-spray mode reactor with Pt catalysts. Appl. Catal. A 2003, 247, 247-259. [CrossRef]

10. Alhumaidan, F.; Cresswell, D.; Garforth, A. Hydrogen storage in liquid organic hydride: Producing hydrogen catalytically from methylcyclohexane. Energy Fuels 2011, 25, 4217-4234. [CrossRef]

11. Gianotti, E.; Taillades-Jacquin, M.; Roziere, J.; Jones, D.J. High-purity hydrogen generation via dehydrogenation of organic carriers: A review on the catalytic process. ACS Catal. 2018, 8, 4660-4680. [CrossRef]

12. Yoon, B.; Pan, H.-B.; Wai, C.M. Relative catalytic activities of carbon nanotube-supported metallic nanoparticles for room temperature hydrogenation of benzene. J. Phys. Chem. C 2009, 113, 1520-1525. [CrossRef]

13. Wang, Y.; Shah, N.; Huffman, G.P. Pure hydrogen production by partial dehydrogenation of cyclohexane and methylcyclohexane over nanotube-supported Pt and Pd catalysts. Energy Fuels 2004, 18, 1429-1433. [CrossRef]

14. Niermann, M.; Beckendorff, A.; Kaltschmitt, M.; Bonhoff, K. Liquid organic hydrogen carrier (LOHC)—Assessment based on chemical and economic properties. Int. J. Hydrogen Energy 2019, 44, 6631-6654. [CrossRef]

15. Niermann, M.; Drünert, S.; Kaltschmitt, M.; Bonhoff, K. Liquid organic hydrogen carriers (LOHCs)-Techno-economic analysis of LOHCs in a defined process chain. Energy Environ. Sci. 2019, 12, 290-307. [CrossRef]

16. Wang, Y.; Shah, N.; Huggins, F.E.; Huffman, G.P. Hydrogen production by catalytic dehydrogenation of tetralin and decalin over stacked cone carbon nanotube-supported Pt catalysts. Energy Fuels 2006, 20, 2612-2615. [CrossRef] 
17. Hodoshima, S.; Arai, H.; Takaiwa, S.; Saito, Y. Catalytic Decalin dehydrogenation/naphthalene hydrogenation pair as a hydrogen source for fuel-cell vehicle. Int. J. Hydrogen Energy 2003, 28, 1255-1262. [CrossRef]

18. Lázaro, M.P.; García-Bordejé, E.; Sebastián, D.; Lázaro, M.J.; Moliner, R. In situ hydrogen generation from cycloalkanes using a Pt/CNF catalyst. Catal. Today 2008, 138, 203-209. [CrossRef]

19. Nagasawa, K.; Sawaguchi, Y.; Kato, A.; Nishiki, Y.; Mitsushima, S. Rate-determining factor of the performance for toluene electrohydrogenation electrolyzer. Electrocatalysis 2017, 8, 164-169. [CrossRef]

20. Nagasawa, K.; Kato, A.; Nishiki, Y.; Matsumura, Y.; Atobe, M.; Mitsushima, S. The effect of flow-field structure in toluene hydrogenation electrolyzer for energy carrier synthesis system. Electrochim. Acta 2017, 246, 459-465. [CrossRef]

21. Bao, Y.; Napporn, T.W.; Nagasawa, K.; Mitsushima, S. Kinetics of toluene electrohydrogenation on Pt/C catalyst. Electrocatalysis 2019, 10, 184-194. [CrossRef]

22. Mitsushima, S.; Takakuwa, Y.; Nagasawa, K.; Sawaguchi, Y.; Kohno, Y.; Matsuzawa, K.; Awaludin, Z.; Kato, A.; Nishiki, Y. Membrane electrolysis of toluene hydrogenation with water decomposition for energy carrier synthesis. Electrocatalysis 2016, 7 , 127-131. [CrossRef]

23. Matsuoka, K.; Miyoshi, K.; Sato, Y. Electrochemical reduction of toluene to methylcyclohexane for use as an energy carrier. J. Power Sources 2017, 343, 156-160. [CrossRef]

24. Higuchi, E.; Ueda, Y.; Chiku, M.; Inoue, H. Electrochemical hydrogenation reaction of toluene with $\mathrm{Pt}_{\mathrm{x}} \mathrm{Ru}$ alloy catalyst-loaded gas diffusion electrodes. Electrocatalysis 2018, 9, 226-235. [CrossRef]

25. Nagasawa, K.; Tanimoto, K.; Koike, J.; Ikegami, K.; Mitsushima, S. Toluene permeation through solid polymer electrolyte during toluene direct electro-hydrogenation for energy carrier synthesis. J. Power Sources 2019, 439, 227070. [CrossRef]

26. Fukazawa, A.; Takano, K.; Matsumura, Y.; Nagasawa, K.; Mitsushima, S.; Atobe, M. Electrocatalytic hydrogenation of toluene using a proton exchange membrane reactor: Influence of catalyst materials on product selectivity. Bull. Chem. Soc. Jpn. 2018, 91, 897-899. [CrossRef]

27. Takano, K.; Tateno, H.; Matsumura, Y.; Fukazawa, A.; Kashiwagi, T.; Nakabayashi, K.; Nagasawa, K.; Mitsushima, S.; Atobe, M. Electrocatalytic hydrogenation of toluene using a proton exchange membrane reactor. Bull. Chem. Soc. Jpn. 2016, 89, 1178-1183. [CrossRef]

28. Inami, Y.; Ogihara, H.; Yamanaka, I. Selective electrohydrogenation of toluene to methylcyclohexane using carbon-supported non-platinum electrocatalysts in the hydrogen storage system. Chem. Select 2017, 2, 1939-1943. [CrossRef]

29. Inami, Y.; Ogihara, H.; Nagamatsu, S.; Asakura, K.; Yamanaka, I. Synergy of Ru and Ir in the electrohydrogenation of toluene to methylcyclohexane on a ketjenblack-supported Ru-Ir alloy cathode. ACS Catal. 2019, 9, 2448-2457. [CrossRef]

30. Inami, Y.; Iguchi, S.; Nagamatsu, S.; Asakura, K.; Yamanaka, I. Disposition of iridium on ruthenium nanoparticle supported on ketjenblack: Enhancement in electrocatalytic activity toward the electrohydrogenation of toluene to methylcyclohexane. ACS Omega 2020, 5, 1221-1228. [CrossRef] [PubMed]

31. $\mathrm{Xu}, \mathrm{G}$. A comparative study on electrocatalytic performance of $\mathrm{PtAu} / \mathrm{C}$ and $\mathrm{PtRu} / \mathrm{C}$ nanoparticles for methanol oxidation reaction. Ionics 2018, 24, 3915-3921. [CrossRef]

32. Chiku, M.; Kunisawa, T.; Higuchi, E.; Inoue, H. Copper chloride as a conversion-type positive electrode for rechargeable aluminum batteries. RSC Adv. 2019, 9, 41475-41480. [CrossRef]

33. Holzwarth, U.; Gibson, N. The scherrer equation versus the 'debye-scherrer equation'. Nat. Nanotechnol. 2011, 6, 534. [CrossRef] [PubMed]

34. Bai, J.; Han, S.-H.; Peng, R.-L.; Zeng, J.-H.; Jiang, J.-X.; Chen, Y. Ultrathin rhodium oxide nanosheet nanoassemblies: Synthesis, morphological stability, and electrocatalytic application. ACS Appl. Mater. Interfaces 2017, 9, 17195-17200. [CrossRef] [PubMed]

35. Miyake, A.; Komasa, S.; Hashimoto, Y.; Komasa, Y.; Okazaki, J. Adsorption of saliva related protein on denture materials: An X-ray photoelectron spectroscopy and quartz crystal microbalance study. Adv. Mater. Sci. Eng. 2016, 2016, 1-9. [CrossRef]

36. Park, J.-E.; Park, S.-G.; Koukitu, A.; Hatozaki, O.; Oyama, N. Electrochemical and chemical interactions between polyaniline and palladium nanoparticles. Synth. Met. 2004, 141, 265-269. [CrossRef]

37. Peuckert, M. XPS study on thermally and electrochemically prepared oxidic adlayers on iridium. Surf. Sci. 1984, 144, 451-464. [CrossRef]

38. Wu, G.; Li, X.; Zhang, Z.; Dong, P.; Xu, M.; Peng, H.; Zeng, X.; Zhang, Y.; Liao, S. Design of ultralong-life Li-CO $\mathrm{C}_{2}$ batteries with $\mathrm{IrO}_{2}$ nanoparticles highly dispersed on nitrogen-doped carbon nanotubes. J. Mater. Chem. A 2020, 8, 3763-3770. [CrossRef]

39. Jin, Z.; Liu, C.; Qi, K.; Cui, X. Photo-reduced $\mathrm{Cu} / \mathrm{CuO}$ nanoclusters on $\mathrm{TiO}_{2}$ nanotube arrays as highly efficient and reusable catalyst. Sci. Rep. 2017, 7, 39695. [CrossRef]

40. Lu, D.; Zelekew, O.A.; Abay, A.K.; Huang, Q.; Chen, X.; Zheng, Y. Synthesis and photocatalytic activities of a CuO/TiO 2 composite catalyst using aquatic plants with accumulated copper as a template. RSC Adv. 2019, 9, 2018-2025. [CrossRef]

41. Hu, Y.; Wu, P.; Yin, Y.; Zhang, H.; Cai, C. Effects of structure, composition, and carbon support properties on the electrocatalytic activity of Pt-Ni-graphene nanocatalysts for the methanol oxidation. Appl. Catal. B 2012, 111-112, 208-217. [CrossRef]

42. Li, H.B.; Yu, M.H.; Wang, F.X.; Liu, P.; Liang, Y.; Xiao, J.; Wang, C.X.; Tong, Y.X.; Yang, G.W. Amorphous nickel hydroxide nanospheres with ultrahigh capacitance and energy density as electrochemical pseudocapacitor materials. Nat. Commun. 2013, 4, 1894. [CrossRef] [PubMed]

43. Chen, X.; Chen, X.; Zhang, F.; Yang, Z.; Huang, S. One-pot hydrothermal synthesis of reduced graphene oxide/carbon nanotube/ $\alpha-$ $\mathrm{Ni}(\mathrm{OH})_{2}$ composites for high performance electrochemical supercapacitor. J. Power Sources 2013, 243, 555-561. [CrossRef] 
44. Isoaho, N.; Sainio, S.; Wester, N.; Botello, L.; Johansson, L.-S.; Peltola, E.; Climent, V.; Feliu, J.M.; Koskinen, J.; Laurila, T. Pt-grown carbon nanofibers for detection of hydrogen peroxide. RSC Adv. 2018, 23, 12472-12751. [CrossRef]

45. Biegler, T.; Rand, D.A.J.; Woods, R. Limiting oxygen coverage on platinized platinum; Relevance to determination of real platinum area by hydrogen adsorption. J. Electroanal. Chem. Interfacial Electrochem. 1971, 29, 269-277. [CrossRef]

46. Nash, J.; Yang, X.; Anibal, J.; Wang, J.; Yan, Y.; Xu, B. Electrochemical nitrogen reduction reaction on noble metal catalysts in proton and hydroxide exchange membrane electrolyzers. J. Electrochem. Soc. 2017, 164, F1712-F1716. [CrossRef]

47. Tokarz, W.; Siwek, H.; Piela, P.; Czerwinski, A. Electro-oxidation of methanol on Pt-Rh alloys. Electrochim. Acta 2007, 52, 5565-5573. [CrossRef]

48. Park, K.-W.; Choi, J.-H.; Ahn, K.-S.; Sung, Y.-E. PtRu alloy and PtRu-WO 3 nanocomposite electrodes for methanol electrooxidation fabricated by a sputtering deposition method. J. Phys. Chem. B 2004, 108, 5989-5994. [CrossRef]

49. Imada, T.; Chiku, M.; Higuchi, E.; Inoue, H. Effect of rhodium modification on activity of platinum nanoparticle-loaded carbon catalysts for electrochemical toluene hydrogenation. ACS Catal. 2020, 10, 13718-13728. [CrossRef]

50. Ferreira, P.J.; la O', G.J.; Shao-Horn, Y.; Morgan, D.; Makharia, R.; Kocha, S.; Gasteiger, H.A. Instability of Pt/C electrocatalysts in proton exchange membrane fuel cells: A mechanistic investigation. J. Electrochem. Soc. 2005, 152, A2256-A2271. [CrossRef]

51. Li, Y.; Wang, H.; Xie, L.; Liang, Y.; Hong, G.; Dai, H. $\mathrm{MoS}_{2}$ nanoparticles grown on graphene: An advanced catalyst for the hydrogen evolution reaction. J. Am. Chem. Soc. 2011, 133, 7296-7299. [CrossRef] [PubMed] 